4. Методика фенологических наблюдений в ботанических садах СССР. - М. : ГБС АН СССР, 1975. - 136 с.

5. Носаль І. М. Від рослини- до людини / І. М. Носаль. - К. : Веселка, 1995. - 448 с.

6. Определитель высших растений Украины / Д. Н. Доброчаева, М. И. Котов, Ю. Н. Прокудин и др. Киев : Наук. думка, 1987. - 548 с.

7. Попов О. П. Лікарські рослини в народній медицині / О. П. Попов. - К. : Здоров’я, 1970. - С. 292-305.

8. Порада О. А. Методика формування та ведення колекцій лікарських рослин / О. А. Порада. - Березоточча, 2007. - $50 \mathrm{c}$.

Кубинская Людмила, Мельничук Елена, Гордийчук Алла. Некоторые аспекты интродукции Scutellaria baicalensis Georgi. в условиях Кременецкого ботанического сада. Определены особености роста и развития Scutellaria baicalensis Georgi при интродукции в условиях Кременецкого ботанического сада. Данные исследований позволяют говорить о перспективности культивирования S. baicalensis в Западной Лесостепи. Растения при размножении семенным методом завязывают цветы и плодоносят, формируя при этом полноценные семена уже с первого года интродукции. В статье описаны и проанализированы способы выращивания шлемника байкальського, указаны основные схемы высева, данные о прохождении фаз роста и развития растений, параметры плодоношения. Интродукционные исследования данного вида направлены на изучение и сохранение $S$. baicalensis в коллекции лекарственных растений.

Ключевые слова: Scutellaria baicalensis, интродукция, семена, всхожесть, энергия прорастания.

Kubynska Ludmyla, Melnychuk Olena, Hordiychuk Alla. Some Aspects of the Introduction of Scutellaria Baicalensis Georgi. in Terms of the Kremenets Botanical Garden. Defined the characteristics of growth and development Scutellaria baicalensis Georgi when introduced in the Kremenets Botanical gardens. The research data allow to speak about the prospects of cultivation of $S$. baicalensis in Western Forest-steppe. Plants in the seed method reproduction knotted flowers and fruit, thus forming the full seeds already from the first year of introduction. The article describes and analyzes how the cultivation of skullcap Baikal, shows the main scheme of sowing, data on the passage of the phases of growth and development of plants, fruiting parameters. Of introduction of this type of research aimed at studying and preserving S. baicalensis in the collection of medicinal plants.

Key words: Scutellaria baicalensis, introduction, seeds, germination, energy of germination..

Стаття надійшла до редколегії 08.04.2016 p.

УДК 502.75(477.8)

Ольга Скакальська, Володимир Баточенко

\title{
Хорологія та особливості зростання Pinguicula vulgaris L. у межах території Бродівського району (с. Батьків, Львівська обл.)
}

У статті повідомляється про знахідку Pinguicula vulgaris L. у межах заболоченої території с. Батьків Бродівського району Львівської обл. Наведено результати дослідження рідкісного, занесеного в Червону книгу України гетеротрофного гелофітного виду P. vulgaris. Подано географічне поширення цього виду, результати геоботанічних, фітоценотичних досліджень, екології місцезростання виду. Висвітлено дані про чисельність особин у ценопопуляції на моніторинговій території. Популяція P. vulgaris L. невелика за площею (до 100 м) малочисельна близько 20-90 особин, росте групами 5-20 на м². Вид входить до складу формації Phragmitetum australis, Cariceta flava, Cariceta nigra, який утворює асоціацію Phragmites australis + Carex flava + Carex nigra.

Ключові слова: Pinguicula vulgaris, моніторинг, гетеротрофний, гелофіт, формація, асоціація, ценопопуляція, особина.

Постановка наукової проблеми та ії значення. В останні п’ятдесят років, а надто ж нині, велике занепокоєння викликає швидка зміна рослинного світу внаслідок антропогенної діяльності, особливо поблизу населених пунктів, що призводить до зникнення корінних екосистем і заміни їх новими, неврівноваженими системами рудерально-сегетального типу. Зникнення цих видів може мати катастрофічні наслідки для біосфери [5, с. 41-46]. Тому в умовах глобальних змін навколишнього природного середовища пріоритетним завданням є теоретико-методологічне обгрунтування, методичні рекомендації та практичні заходи охорони фіторізноманіття як середовищетвірної основи збалансованого розвитку біосфери. За посиленого антропогенного впливу, трансформації біотопів

(C) Скакальська О., Баточенко В., 2016 
потрібно встановити еколого-хорологічні особливості рідкісних, зникаючих рослин, рекомендувати созономічні критерії їх збереження й відтворення. Особливо важливі вищезазначені проблеми для одних із найбільш вразливих до осушувально-меліоративних наслідків - гетеротрофних гелофітів, зокрема видів роду Pinguicula L.

Аналіз досліджень цієї проблеми. Унаслідок антропічного впливу на довкілля, проведення осушувальних робіт, видобування торфу багато потенційних екотопів гелофітів утрачено. Навіть в об'єктах природно-заповідного фонду стан популяцій рідкісних болотних рослин, а caмe Pinguicula погіршується. Це пов'язано з природними процесами сукцесій, сильватизацією, зміною гідрологічного режиму, трансформацією екотопів тощо.

Мета роботи - виявлення рослинних угруповань за участю товстянки, вивчення фітоценотичних особливостей цих угруповань, хорології та сучасного стану ценопопуляцій $P$. vulgaris.

Матеріали й методи дослідження. В основу роботи покладено матеріали польових досліджень 2014 р., проведених маршрутно-пошуковим методом із фотографуванням і складанням геоботанічних описів за [4, с. 256] та за загальноприйнятими методиками [2, с. $155 ; 6$, с. 449; 3, с. 11-16]. Отримані результати опрацьовано статистично на ПК із використанням програм Microsoft Office World та Microsoft Office Excel, 2003, 2007; номенклатуру видів подано згідно з Vascular plants of Ukraine [10, с. 345]. Окрім оригінальних досліджень, для хорологічного аналізу видів рослин критично опрацьовано літературні дані й матеріали з фондів гербаріїв Інституту ботаніки ім. М. Г. Холодного НАН України (KW), Рівненського обласного краєзнавчого музею (ROKM), Національного ботанічного саду ім. М. М. Гришка (KWHA), Львівського національного університету ім. I. Я. Франка (LW), Львівського природничого музею НАН України (LWS), Інституту екології Карпат (LWE).

Виклад основного матеріалу й обгрунтування отриманих результатів дослідження. Під час геоботанічного обстеження заболоченої території с. Батьків Бродівського району Львівської області (316-320 м висота над р. м, карбонатне евтрофне осоково-різнотравне болото площею 7 га) виявлено місцезростання $P$. vulgaris.

P. vulgaris гемікриптофіт, рідкісний, комахоїдний вид, висотою до 20 см із родини Lentibulariaceae. Листки в прикореневій розетці, довгасто-еліптичні, зверху вкриті клейкими залозками (рис. 1). Квітконосне стебло безлисте, з однією квіткою. Віночок синювато-фіолетовий, шпорка шилоподібна. Цвіте в червні-серпні, плодоносить у серпні-вересні. Розмножується насінням, яке дуже дрібне й розноситься вітром [9, с. 912].

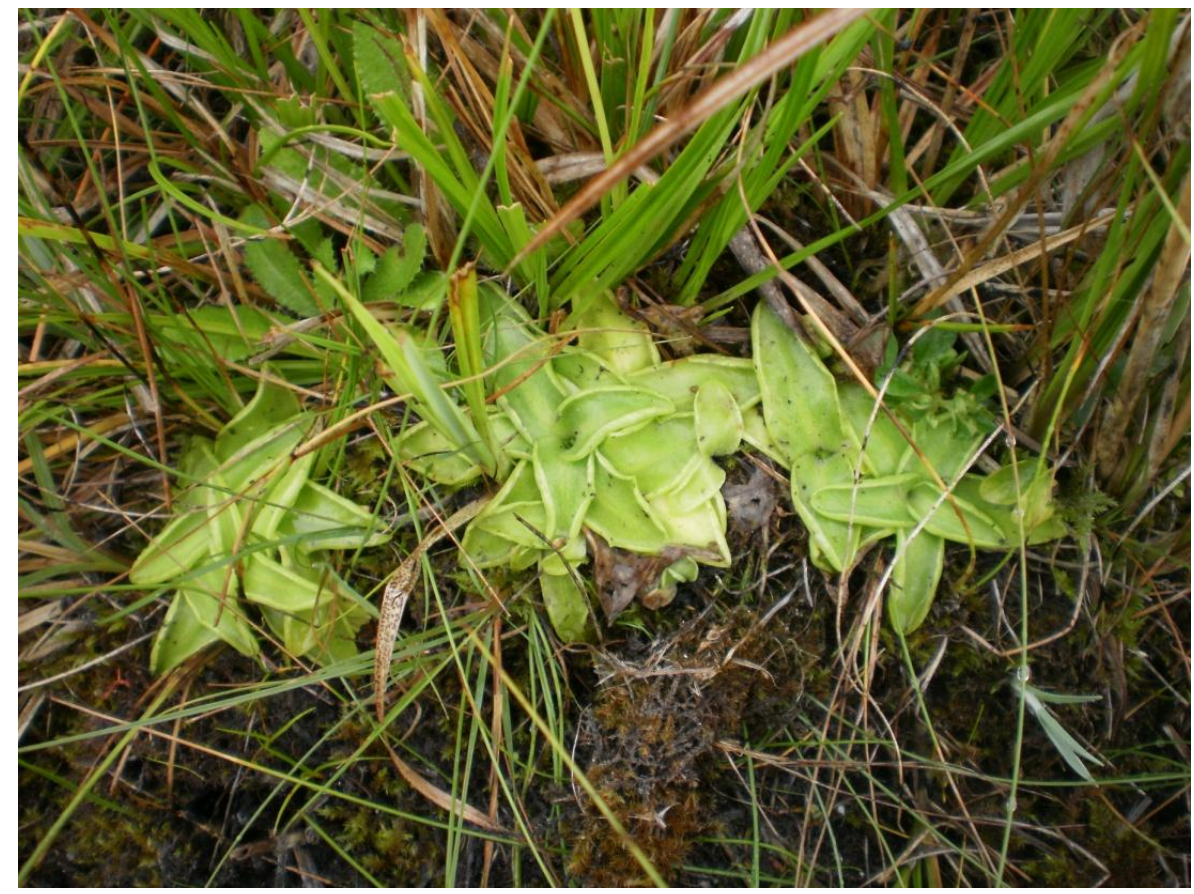

Рис. 1. Гетеротрофний гелофiт - Pinguicula vulgaris

За опрацьованими літературними та гербарними даними, хорологічна характеристика $P$. vulgaris $\epsilon$ такою: 
- Закарпатська область - Рахівський район - г. Стіг (Вайщук, 1955, LWS), хребет г. Свидовець (Тасьянкевич, 1982, LWS), хребет г. Свидовець, полонина Крачунєска, болото на схилі (Борсукевич, 2007, LWS), хребет г. Свидовець полонина Драгобрат (Данилик, 1987, LW), с. Ясіня, г. Жандарми (Кардаш, Гинда, 1986, LW).

- Львівська обл. - Золочівський р-н. - околиці с. Зарваниця (Кузярин, 1991, LWS, Скакальська та ін. 2014, гербарій інституту агроекології і природокористування НААН України м. Київ), [7, с. 428-430], с. Миколаїв болото Печенія (Кузярин, 1993, LWS), околиці с. Скнилів (Konlny, 1976, LWS), Перемишлянський р-н. - с. Романів (Бухало, 1959, LW).

- Рівненська обл. - Здолбунівський р-н. - с. Батьківці (Андрієнко, Антонова, 1983, ROKM), c. Устенськ болото Подзастав'€ (Антонова, 1984, ROKM), Острозький p-н. - Бущанський ботанічний заказник загальнодержавного значення [8, с. 367-370], Радивилівський р-н. - с. Пляшева (Андрієнко, Антонова, 1982, ROKM), Млинівський р-н. - с. Хорупань-Мятин (Антонова, 1987, ROKM), с. Товпижин (Антонова, 1987, ROKM), с. Вийніца-Бокийма (Антонова, Степанюк, 1989, ROKM).

- Волинська обл. - м. Шацьк (Мельник, 1978, LWS), с. Жизниковське (Ракочин, 1904, LWS), с. Мельники болото Уничі (Гончаренко, 1998; Софієна, Рачкевич, 2004, LW), берег озера Красинець (Гончаренко, 2005, LW).

Наводимо відомості про сучасний стан виявлених ценопопуляцій $P$. vulgaris та фітоценотичну характеристику рослинних угруповань за участю цього виду.

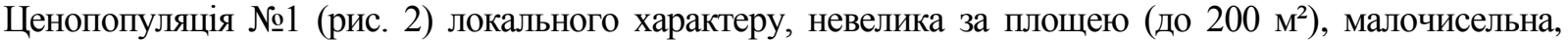
рослини ростуть групами 3 5-20 особин на $1 \mathrm{~m}^{2}$. Ценопопуляція входить до складу асоціації Phragmites australis + Carex flava, що належить до формації Phragmitetum australis. Загальне проективне покриття трав'яного покриву становить $55 \%$. Окрім домінантів Phragmites australis Cav. Trin. ex Steud. - (30\%), Triglochin palustre L. - (10\%), Carex flava L. - (20\%), Juncus effusus L. - (10\%) y формуванні рослинного покриву беруть участь також Parnassia palustris L., Valeriana officinalis L., Eupatorium cannabinum L., Achillea millefolium L., Eleocharis palustris L., Equisetum palustre L., Lycopus europaeus L., Myosotis palustris (L.) Lam., Prunella vulgaris L., Potentilla erecta (L.) Hampe, Menyanthes trifoliata L. - регіонально-рідкісний вид, проективне покриття кожного 3 цих видів не перевищує $1 \%$.

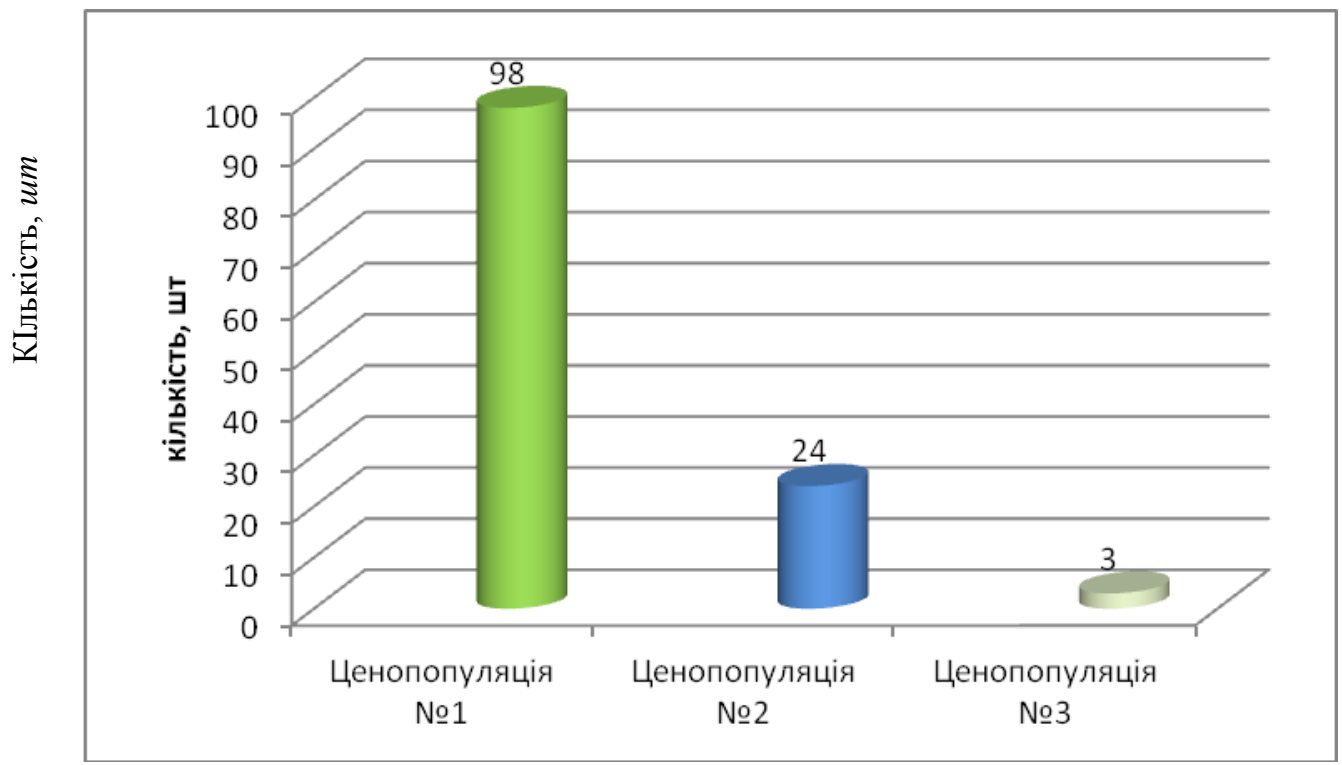

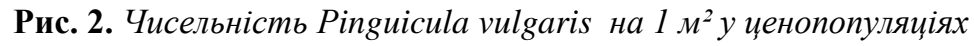

Підріст утворений із Salix cinerea L., Salix trianata L. проективне покриття менше $1 \%$.

Ценопопуляція № 2 (рис. 2) локального характеру, невелика за площею (до 100 м²), малочисельна, рослини ростуть поодиноко й групами по 5-10 особин на $1 \mathrm{~m}^{2}$. Вид входить до складу формації Phragmitetum australis, що утворює асоціації Phragmites australis + Juncus effusus + Carex nigra. Окрім домінантів Juncus effusus, Phragmites australis, Carex nigra із проективним покриттям 
20-30 \%, відповідно, у складі трав'яного покриву також виявлено Carex flava, Lycopus europaeus, Parnassia palustris, Cirsium palustre (L.) Coss. ex Scop., Poa pratensis L. Більшість цих видів має проективне покриття до $1 \%$ лише Carex flava 5 \%. Підріст утворений такими самими видами, як і в попередньому угрупованні, але в його складі виявлено Salix purpurea L. проективне покриття менше $1 \%$.

Ценопопуляція № 3 (рис. 2) малочисельна, рослини ростуть поодиноко - три особини на 1 м². Найбільш пошкоджена внаслідок випасання худоби. Вид входить до входить до складу формації Caricetum nigra, що утворює асоціації Carex nigra+ Cirsium palustre. Травостан представлено ценозами з домінуванням Achillea millefolium, Myosotis palustris. В угруповання також входить Parnassia palustris, Lycopus europaeus, Valeriana officinalis, Eupatorium cannabinum, Prunella vulgaris, Menyanthes trifoliata (відповідно, проективне співвідношення - менше $1 \%$ ).

Зважаючи на літературні джерела та власні дослідження, очевидно, що значна кількість локалітетів цього виду вже докорінно трансформована внаслідок широкомасштабних осушувальних робіт і на сьогодні $P$. vulgaris потрібно розглядати як швидкозникаючий.

Висновки та перспективи подальших досліджень. Отже, обстежені ценопопуляції є малочисельними, їхні вікові спектри не завжди повночленні, негативний вплив на природне самовідновлення популяцій товстянки має проникнення худоби на територію місцезростань виду, унаслідок чого пошкоджуються дорослі особини в межах популяцій. Окремі 3 них є дуже унікальними й потребують дбалої охорони. Тому задля збереження цінних $P$. vulgaris потрібно забезпечити охорону їхніх природних локалітетів із дотриманням режиму заповідності. Актуальним є проведення регулярних екомоніторингових досліджень, на основі яких можна буде оцінювати життєвий стан популяцій, спрогнозувати динамічні тенденції та можливі наслідки змін.

\section{Джерела та література}

1. Андрієнко Т. Л. Комахоїдні рослини України / Т. Л. Андрієнко. - К. : Альтерпрес, 2010. - 80 с.

2. Байдеман И. М. Методика изучения фенологии растений и растительных сообществ. - Новосибирск : Наука, 1974. - 155 с.

3. Голубев В. Н. К методике эколого-биологических исследований редких и исчезающих растений в естественных условиях / В. Н. Голубев // Бюллетень Никитского ботанического сада. - 1982., В. 47 C. $11-16$.

4. Григора I. М. Польовий практикум з ботаніки : навч. посіб. / І. М. Григора, Б. Є. Якубенко. - К. : Арістей, 2005 - С. 256.

5. Попов С. Ю. Раритетне дендрорізноманіття: проблематика та охорона / С. Ю. Попович, О. М. Корінько // Рослинний світ у Червоній книзі України: реалізація Глобальної стратегії збереження рослин : матеріали Міжнар. наук. конф. - К. : Альтерпрес, 2010. - С. 41-46.

6. Работнов Т. А. Методы изучения семенного размножения травянистых растений в сообществе / Т. А. Работнов // Полева геоботаніка. - М. ; Л. : Изд-во АН СССР, 1960. - 449 с.

7. Скакальська О. І. Дослідження Pinguicula vulgaris L. в межах басейну річки Золочівка / O. I. Скакальська, В. М. Баточенко, I. О. Скоропляс // Біологічні дослідження - 2014 : матеріали V наук.-практ. конф., м. Житомир, 4-5 берез. 2014 р. - С. 428-430.

8. Скакальська O. I. Сучасний стан ценопопуляцій Pinguicula vulgaris L. в межах території Бущанського ботанічного заказника / О. І. Скакальська, І. О. Скоропляс // Вісник Харківського національного університету імені В. Н. Каразіна. - №1100. - Серія «Біологія». - Вип. 20. - Х., 2014. - С. 367-370.

9. Червона книга України. Рослинний світ / за ред. Я. П. Дідуха. - К. : Глобалконсалтинг, 2009. - 912 с.

10. Mosyakin S. L. Vascular plants of Ukraine. A nomevclaturar checklist / S. L. Mosyakin, M. M. Fedoronchouk. - Kiev : M. G. Kholodny Institute of Botany, 1999. - 345 p.

Скакальская Ольга, Баточенко Владимир. Хорология и особенности роста Pinguicula vulgaris L. в пределах территории Бродовского района (с. Батьков, Львовская обл.). В статье сообщается о находке Pinguicula vulgaris L. в пределах заболоченной территории с. Батьков, Бродовского района Львовской обл. Приведены результаты исследования редкого, занесенного в Красную книгу Украины гетеротрофного гелофитного вида P. vulgaris. Подается географическое распространение данного вида, результаты геоботанических, фитоценотических исследований, экологии местопроизростания вида. Освещены данные о численности особей в ценопопуляции на мониторинговой территории. Популяция P. vulgaris L. небольшая за 
площадью (до 100 м), малочисленная (около 20-90 особей), растет группами по 5-20 на м². Вид входит в состав формации Phragmitetum australis, Cariceta flava, Cariceta nigra, который образует ассоциации Phragmites australis + Carex flava + Carex nigra.

Ключевые слова: Pinguicula vulgaris, мониторинг, гетеротрофный, гелиофиты, формация, ассоциация, ценопопуляция, особь.

Skakal's'ka Olga, Batochenko Volodumur. Chorology and Growth Characteristics Pinguicula Vulgaris L. Within the Territory of Brody District (p. Batkov, Lviv Region.). The article reported the discovery Pinguicula vulgaris L. within wetlands with. Batkiv, Brody district, Lviv region. The results of the study of rare, listed in the Red Book of Ukraine heterotrophic heterotrophic species $P$. vulgaris. Posted geographical spread of this type, the results of geobotanical, phytocoenotic research, ecology habitat type. Deals with the data on the number of individuals in coenopopulations in the monitoring area. The population of P. vulgaris L. small area (100 m) of small, about 20-90 individuals, groups grows 5-20 $\mathrm{m}^{2}$. Type part of the formation Phragmitetum australis, Cariceta flava, Cariceta nigra, which forms association Phragmites australis + Carex flava + Carex nigra.

Key words: Pinguicula vulgaris, monitoring, heterotrophic, heliofit, formation, association, coenopopulations, individual.

Стаття надійшла до редколегії 16.02.2016 p.

УДК $581.93(477.8)$

\author{
Марія Стасюк, \\ Сергій Лико
}

\title{
Історія вивчення адвентивної фракції флори Волинської височини
}

У флорі України зараз немає жодного флорокомплексу, у якому б не брали участь адвентивні рослини. Інвазійні адвентивні рослини вкорінюються навіть у деревно-чагарникових ценозах, які мають найбільш стійку структуру.

Упродовж усієї історії дослідження рослинного світу Волинської височини спеціального вивчення видового складу, поширення адвентивних рослин, їхніх еколого-ценотичних умов зростання, структури популяцій не проводили. Проте в працях деяких науковців наведено фрагментарні відомості про видовий склад рослин окремих міст і їхніх околиць, які представлені в загальних флористичних зведеннях.

У статті досліджено перші відомості про флору Волинської височини, наведені на початку XIX ст. в роботах В. Г. Бессера, Фогеля, Й. Юндзіла, В. С. Доктуровського. Проте вчені не вказували конкретних місцезнаходжень більшості видів. Окремі види адвентивних рослин у межах території Волинської височини описано в працях ботаніків із другої половини XIX ст.: О. С. Роговича, В. В. Монтрезора, Й. К. Пачоського, І. Ф. Шмальгаузена, М. А. Троїцького, Й. Панека, С. Мацко, А. І. Барбарича. Однак у цих роботах адвентивні рослини в окрему групу не виділено.

Ключові слова: адвентивна фракція флори, Волинська височина, історія вивчення.

Постановка наукової проблеми та їі значення. У флорі України зараз немає жодного флорокомплексу, у якому б не брали участь адвентивні рослини [12]. Вивчення неаборигенної фракції флори України розпочалося з окремих видів заносних рослин разом із видами природної флори й на початкових етапах проводилося переважно окремими вченими та флористами університетів, які, подорожуючи в межах порівняно невеликих територій, досліджували місцеву флору.

Аналіз досліджень цієї проблеми. Волинська височина, або Волинське лесове плато, лежить у південно-західній, найбільш припіднятій частині Східноєвропейської рівнини. Вона є складовою частиною Волино-Подільської височини та являє собою іiі північну частину, виокремлену від Подільської височини вузькою смугою Малого Полісся. На півночі Волинське лесове плато межує 3 Поліською низовиною, на сході - із Житомирським Поліссям, на заході - із Люблінською височиною, від якої Волинське плато відмежоване долиною р. Західний Буг [7].

У зв'язку з особливостями природних і соціально-історичних умов процеси адвентизації флори на території Волинської височини, на відміну від південних регіонів України, ще декілька десятиріч

(C) Стасюк М., Лико С., 2016 